\title{
Dormancy breaking in seeds of different accessions of Luffa cylindrica Roemer
}

Francisca Sonally Oliveira*, Lindomar Maria da Silveira, Salvador Barros Torres, Ferdinando Monteiro Carvalho Dias da Costa, Maclayver Christiano Caetano Nunes, José Sisenando de Senna e Silva Neto

Federal Rural University of the Semi-Arid, Mossoró, Brazi *Corresponding author, e-mail: sonallyson@hotmail.com

\begin{abstract}
Luffa cylindrica Roemer is abundant in countries of Asia, Central America and South America. Dormancy in luffa seeds is caused by the impermeability of the coat, which may be a major obstacle in the commercial production of seedlings for the cultivation of this species. Thus, this study aimed to evaluate different methods to break dormancy in different accessions of luffa. The experimental design was completely randomized, in a 6 (accessions) x 5 (dormancy breaking treatments) factorial arrangement, with four replicates. Seeds were planted on expanded polystyrene trays, containing commercial substrate Plantmax ${ }^{\circledast}$. The analyzed variables were: emergence percentage; emergence speed index; number of true leaves; plant height; stem diameter; root length; shoot fresh and dry matter, and root dry matter. The first two variables were analyzed in the entire experimental plot and the others only in the evaluated area of the plot. Scarification with sandpaper $n^{\circ} 80$ and cut with pruning pliers on the opposite end to the hilum were the methods of dormancy breaking which led to the best results. Due to the variability of the results among the accessions, it was not possible to recommend one method of dormancy breaking for luffa seeds that is generalized for all of them.
\end{abstract}

Keywords: Luffa cylindrica, emergence, medicinal plant

\section{Introduction}

Luffa cylindrica Roemer, popularly known as loofah, Cucurbitaceae family, is a subtropical, annual, herbaceous plant that is abundant in China, Japan and other Asian countries, as well as in countries of Central and South America (Braga, 1979). This species is usually grown in small areas and mostly by small farmers (Leite et al., 2011). Since its market value is high and has remained stable for the last years, the cultivated area has expanded in several regions of Brazil and the demand for information on its cultivation has increased.

Although luffa seeds are available at the market, the cultivation of this cucurbit is mostly conducted using seeds collected from spontaneous plants. Thus, some problems have been observed, mainly because the species reproduces by crossing, which leads to variability in various traits. Among them, dormancy stands out, which in luffa is caused by the impermeability of the coat (Moreira et al., 2007a) and may be a major obstacle in the commercial production of seedlings for the cultivation of this species.

Dormancy is an adaptive characteristic that ensures the survival of the species in the different ecosystems, contributing to its perpetuation in the agricultural cultivation (Vivian et al., 2008). Dormancy caused by factors inherent to the seed coat can be interrupted 
by scarification, a term that applies to any treatment which causes rupture or weakening of the coat, allowing germination to occur. In nature, this process involves the participation and interaction of microorganisms and alternated temperatures, besides the activity of predatory animals (Carvalho \& Nakagawa, 2012).

Several studies confirm the advantage of using dormancy breaking methods to increase germination percentage. Silva et al. (2012) tested different methods to break dormancy in seeds of Cassia grandis L., whereas Gnoatto \& Cruz-Silva (2011) worked with seeds of Brazilian ironwood (Caesalpinia ferrea Mart. ex Tul. var. leiostachya Benth.).

Advantages were also reported by Moreira et al. (2007a), who worked with luffa seeds, using pre-germination treatments with mechanical scarification using sandpaper $n^{\circ}$ 80 and cut on the opposite end to the hilum, obtaining $100 \%$ emergence of seedlings, whereas the control treatment had 13\%. Aragão et al. (2006) also achieved higher percentages of germination in seeds of watermelon (Citrullus lanatus (Thunb) Mansf) using scarification, reaching germination of up to $92 \%$. Parreira et al. (2012), after studying different methods in bitter melon (Momordica charantia L.), recommend the use of concentrated sulfuric acid for $3 \mathrm{~min}$ to increase the germination percentage of this species.

Therefore, this study aimed to evaluate different methods of dormancy breaking in seeds of different accessions of Luffa cylindrica Roemer.

\section{Material and Methods}

The experiment was carried out in a greenhouse at the Department of Agronomical and Forestry Sciences of the Center of Agrarian Sciences of the Federal Rural University of the Semi-Arid Region (UFERSA), Mossoró/RN, Brazil $\left(5^{\circ} 11^{\prime} \mathrm{S}, 37^{\circ} 20^{\prime} \mathrm{W}\right.$ and $18 \mathrm{~m}$ of altitude). Six accessions of luffa seeds, collected in different municipalities of the northeastern region of Brazil, were used.

The experimental design used was completely randomized, in $6 \times 5$ factorial arrangement, with four replicates. The first factor consisted of six accessions (Apodi, Apodi $_{2^{\prime}}$
Apodi $_{3^{\prime}}$ Apodi $_{4^{\prime}}$ Petrolina, and Serra Talhada $)_{1}$, of which Apodi ${ }_{1}$, Apodi $_{2}$, Apodi $_{3}$ and Apodi were collected in the municipality of Apodi/RN (latitude: 5०38'58'S and longitude: 3747'45"W); the accession Petrolina ${ }_{1}$ was collected in the municipality of Petrolina/PE (latitude: 9²3'39"s and longitude: 40'30'35'W) and the accession Serra Talhada, was collected in the municipality of Serra Talhada/PE (latitude: 7059'7"S and longitude: $38^{\circ} 17^{\prime} 34^{\prime \prime} \mathrm{W}$ ). All seeds were in perfect phytosanitary conditions. The second factor were the dormancy breaking treatments: control $\left(T_{1}\right)$, scarification with sandpaper $n^{\circ} 80\left(T_{2}\right)$ - seeds were sanded on the opposite end to the hilum; scarification with pruning pliers $\left(T_{3}\right)$ - a small cut was made on the opposite end to the hilum, and immersion in water at two temperatures: $60^{\circ} \mathrm{C}\left(\mathrm{T}_{4}\right)$ and $80^{\circ} \mathrm{C}\left(\mathrm{T}_{5}\right)$ - water was heated up to the desired temperatures, seeds were then immersed and remained under such condition until water temperature decreased back to room temperature. In total, there were 30 treatments.

After being subjected to the treatments, the seeds were planted on expanded polystyrene trays with 128 cells, containing Plantmax ${ }^{\circledR}$ commercial substrate for production of cucurbit seedlings, and irrigated. Before being used, the trays were washed in running water and immersed in sodium hypochlorite solution at proportion of 1 $\mathrm{mL} \mathrm{L}^{-1}$ of water and neutral detergent at the same proportion. Each plot consisted of 24 cells (three rows), and the evaluated area of the plot was represented by the central row, disregarding the plants at each end, in a total of six cells. Irrigations were performed every day, twice a day.

The variables analyzed were: emergence percentage (EP) - obtained by final count of the seedlings emerged at 14 days after sowing, with data expressed in percentage, and considering as emerged those seedlings with fully expanded cotyledons; emergence speed index (ESI) - the seedlings emerged until 14 days after sowing, from the first seedling emerged, were counted every day at the same time, and the index was calculated according to the model proposed by Maguire (1962); number of true leaves (NTL) - determined by final count of the number of expanded true leaves on each plant at harvest; plant height $(\mathrm{PH})$ - measured using a graduated 
ruler $(\mathrm{cm})$, considering the length from the collar of the seedling to its apex; stem diameter (SD) - measured with a digital caliper at the height of the seedling collar, with values expressed in $\mathrm{cm}$; root length (RL) - obtained by measuring the roots using a ruler graduated in $\mathrm{cm}$; shoot fresh matter (SFM) - obtained by weighing the shoots at harvest on a digital scale, with values expressed in grams; root dry matter (RDM) and shoot dry matter (SDM) - obtained by weighing roots and shoots on analytical scale, after drying in forced air circulation oven at $60^{\circ} \mathrm{C}$ for 24 hours, with mean results expressed in grams. The first two variables were analyzed in the entire experimental plot, whereas the others were analyzed in the evaluated area of plot.

\section{Results and Discussion}

Significant differences were found in emergence percentage, emergence speed index, stem diameter and shoot dry matter of the seedlings (Table 1).

Table 1. Mean values of emergence, emergence speed index, stem diameter and shoot dry matter of luffa (Luffa cylindrica Roemer) seedlings grown from accessions of seeds subjected to different dormancy breaking methods

\begin{tabular}{|c|c|c|c|c|c|}
\hline \multirow{2}{*}{ Accessions } & \multicolumn{5}{|c|}{ Emergence (\%) } \\
\hline & $\mathrm{Tl}$ & $\mathrm{T} 2$ & T3 & $\mathrm{T} 4$ & T5 \\
\hline Apodi $_{1}$ & $54 \mathrm{bcB}^{*}$ & $93 a A$ & $95 \mathrm{aA}$ & $54 \mathrm{bcB}$ & $46 \mathrm{CB}$ \\
\hline Apodi $_{2}$ & $60 \mathrm{bcB}$ & $92 \mathrm{aA}$ & $94 \mathrm{aA}$ & $62 \mathrm{bcB}$ & $79 \mathrm{abAB}$ \\
\hline $\mathrm{Apodi}_{3}$ & $76 \mathrm{abB}$ & $100 \mathrm{aA}$ & $99 \mathrm{aAB}$ & $77 \mathrm{abB}$ & $44 \mathrm{cC}$ \\
\hline Petrolina, & $92 \mathrm{aA}$ & $100 a A$ & $97 \mathrm{aA}$ & $92 \mathrm{aA}$ & $99 \mathrm{aA}$ \\
\hline Apodi $_{4}$ & $91 \mathrm{aA}$ & $91 \mathrm{aA}$ & $95 \mathrm{aA}$ & $88 \mathrm{aA}$ & $86 a b A$ \\
\hline \multirow[t]{2}{*}{ Serra Talhada } & $51 \mathrm{CBC}$ & $97 \mathrm{aA}$ & $99 \mathrm{aA}$ & $47 \mathrm{cC}$ & $72 \mathrm{bB}$ \\
\hline & \multicolumn{5}{|c|}{ Emergence speed index } \\
\hline Apodi $_{1}$ & $7,11 \mathrm{bB}^{*}$ & $17,52 \mathrm{bA}$ & $19,94 \mathrm{aA}$ & $7,81 \mathrm{bB}$ & $6,71 \mathrm{CB}$ \\
\hline Apodi $_{2}$ & $7,80 \mathrm{bc}$ & $18,66 \mathrm{bAB}$ & $21,61 \mathrm{aA}$ & $12,61 \mathrm{abBC}$ & $13,78 \mathrm{bcBC}$ \\
\hline Apodi $_{3}$ & $13,84 \mathrm{abB}$ & $21,97 \mathrm{abA}$ & $20,68 \mathrm{aAB}$ & $16,73 \mathrm{aAB}$ & $6,43 \mathrm{cC}$ \\
\hline Petrolina & $16,31 \mathrm{aB}$ & 27,39 aA & $23,22 \mathrm{aAB}$ & $18,31 \mathrm{aB}$ & $25,92 \mathrm{aA}$ \\
\hline Apodi $_{4}$ & $12,55 \mathrm{abB}$ & $18,09 \mathrm{bAB}$ & $22,70 \mathrm{aA}$ & $13,71 \mathrm{abB}$ & $19,48 \mathrm{abAB}$ \\
\hline \multirow[t]{2}{*}{ Serra Talhada } & $6,50 \mathrm{bB}$ & $18,64 \mathrm{bA}$ & $20,38 \mathrm{aA}$ & $7,70 \mathrm{bB}$ & $8,39 \mathrm{CB}$ \\
\hline & \multicolumn{5}{|c|}{ Stem diameter $(\mathrm{cm})$} \\
\hline Apodi $_{1}$ & $0,27 a b A^{*}$ & $0,31 \mathrm{aA}$ & $0,29 \mathrm{aA}$ & $0,28 \mathrm{bA}$ & $0,28 \mathrm{aA}$ \\
\hline Apodi $_{2}$ & $0,26 \mathrm{abA}$ & $0,30 a A$ & $0,29 \mathrm{aA}$ & $0,28 \mathrm{bA}$ & $0,28 a A$ \\
\hline Apodi $_{3}$ & $0,30 \mathrm{aA}$ & 0,31 aA & 0,29 aA & $0,33 a A$ & 0,30 aA \\
\hline Petrolina & $0,27 \mathrm{abA}$ & 0,31 aA & $0,29 a A$ & $0,27 \mathrm{bA}$ & 0,31 aA \\
\hline Apodi $_{4}$ & $0,23 \mathrm{bB}$ & $0,28 a A$ & 0,31 aA & $0,27 \mathrm{bAB}$ & $0,28 \mathrm{aA}$ \\
\hline \multirow[t]{2}{*}{ Serra Talhada } & $0,28 \mathrm{abA}$ & $0,28 a A$ & $0,28 \mathrm{aA}$ & $0,28 \mathrm{bA}$ & $0,28 a A$ \\
\hline & \multicolumn{5}{|c|}{ Shoot dry matter (g) } \\
\hline Apodi $_{1}$ & 0,07 a A* & $0,99 \mathrm{aA}$ & $0,10 a \mathrm{~A}$ & $0,04 \mathrm{cA}$ & 0,96 aA \\
\hline Apodi $_{2}$ & $0,12 \mathrm{aAB}$ & $0,14 \mathrm{aAB}$ & $0,11 \mathrm{aAB}$ & $0,19 \mathrm{aA}$ & $0,08 \mathrm{abB}$ \\
\hline $\mathrm{Apodi}_{3}$ & $0,12 \mathrm{aAB}$ & $0,15 \mathrm{aA}$ & $0,15 a A$ & $0,15 \mathrm{abA}$ & $0,04 \mathrm{bB}$ \\
\hline Petrolina & $0,09 \mathrm{aA}$ & $0,14 \mathrm{aA}$ & $0,12 \mathrm{aA}$ & $0,12 \mathrm{abcA}$ & $0,15 \mathrm{aA}$ \\
\hline Apodi $_{4}$ & $0,04 \mathrm{aB}$ & $0,11 \mathrm{aAB}$ & $0,12 \mathrm{aAB}$ & $0,07 \mathrm{bcAB}$ & $0,14 \mathrm{aA}$ \\
\hline Serra Talhada & $0,05 \mathrm{aA}$ & $0,13 a A$ & $0,11 \mathrm{aA}$ & $0,05 \mathrm{cA}$ & $0,07 \mathrm{abA}$ \\
\hline
\end{tabular}

For the emergence speed index, difference was observed among all accessions, except for the treatment in which seeds were cut on the opposite end to the hilum - T3 (Table 1). The accession Petrolina, was superior to the others in all treatments evaluated, despite being similar to $\mathrm{Apodi}_{3}$ and $\mathrm{Apodi}_{4}$ for the control - T1, to $\mathrm{Apodi}_{3}$ for scarification with sandpaper $\mathrm{n}^{\circ} 80$ T2, to Apodi $_{2}$ Apodi $_{3}$ and Apodi for immersion in water at $60^{\circ} \mathrm{C}-\mathrm{T} 4$, and to $\mathrm{Apodi}_{4}$ for immersion in water at $80^{\circ} \mathrm{C}-\mathrm{T} 5$. In the simple-effect analysis of treatments for each accession, the treatment with cut on the opposite end to the hilum was superior to the others, although similar to the treatment of scarification with sandpaper for all accessions (Table 1). Similar results were found by Moreira et al. (2007a) with luffa seeds. These authors observed that the treatments of scarification with sandpaper and cut on the opposite end to the hilum led to better results for emergence speed 
index. Also in this regard, Araújo et al. (2015), studying seeds of Luffa operculata (L.) Cogniaux, observed that mechanical scarification was the best treatment in terms of emergence speed index. These authors found value of 3.00 for this variable, whereas in the present study the results varied from 17.52 to 27.39 , depending on the accession used. This suggests that luffa seeds are more sensitive to this treatment.

For the emergence of seedlings, there was difference between the accessions for the treatments control $-\mathrm{Tl}$ and immersion in water at $60^{\circ} \mathrm{C}$ and at $80^{\circ} \mathrm{C}-\mathrm{T} 4$ and $\mathrm{T} 5$, respectively, with no significant difference for the other treatments (Table 1). The accession Petrolina, was superior to the others for all treatments. On the other hand, in the analysis of treatments for each accession, there was significant difference between treatments for Apodi ${ }_{1}$, Apodi $_{2}$, Apodi $_{3}$ and Serra Talhada $_{1}$. The treatments with scarification using sandpaper - T2 and cut with pruning pliers - T3 were superior to the others for all accessions. Alves et al. (2007), with seeds of Caesalpinia pyramidalis Tul, observed that the treatment with manual scarification using a sandpaper resulted in higher emergence percentage, whereas tip removal in the region opposite to the hilum was not efficient because, according to the authors, it did not allow seeds to express their maximum physiological potential. Araujo et al. (2015), testing several dormancy breaking methods for Luffa operculata (L.) Cogniaux, found higher percentages of germination and emergence when using scarification with sandpaper $\mathrm{n}^{\circ} 80$. Dutra \& Medeiros Filho (2009) observed increase of germination percentage in seeds of lebbeck tree (Albizia lebbeck L. Benth.) when using the treatments of mechanical scarification, sandpaper $n^{\circ} 120$ and sulfuric acid for $5,10,15$, 20, 30 and 45 minutes, showing that scarification with sandpaper is a very widespread and efficient method.

For the results of stem diameter, there was no significant difference between the accessions in the treatments with sandpaper $n^{\circ} 80-\mathrm{T} 2$, cut on the opposite end to the hilum - T3 and immersion in water at $80^{\circ} \mathrm{C}-\mathrm{T} 5$, whereas the accession $\mathrm{Apodi}_{3}$ was superior for the control treatment - $\mathrm{Tl}$ and in the treatment with immersion in water at $60^{\circ} \mathrm{C}$ -
T4 (Table 1). In the analysis of treatments for each accession, all treatments were statistically similar. In relation to shoot dry matter, the results differed among the accessions in the treatments with immersion in water at $60^{\circ} \mathrm{C}$ and $80^{\circ} \mathrm{C}-\mathrm{T} 4$ and $\mathrm{T} 5$, and there were no significant differences for the other treatments (Table 1). The accession Apodi $_{2}$ was superior to the others for $\mathrm{T} 4$, and the accession Apodi, was superior to the others for T5. Considering the analysis of the interaction in the other direction, treatments for each accession, it was possible to observe that there was significant difference between treatments for Apodi $_{2^{\prime}}$ Apodi $_{3}$ and Apodi $_{4}$, with no significant difference between treatments for Apodi, Petrolina ${ }_{1}$ and Serra Talhada ${ }_{1}$. The treatment T4 was superior to the others for the accession Apodi ${ }_{2}$, as well as T5 for Apodi $_{4}$ and the treatments T2, T3 and T4 for Apodi $_{3}$. In this regard, Moreira et al. (2007a) and Moreira et al. (2007b), evaluating pre-germination treatments for luffa seeds, observed that the best results of shoot dry matter were obtained in seedlings grown from seeds subjected to treatments with sandpaper and pruning pliers. The same result was found by Pereira et al. (2015), analyzing seeds of Pithecellobium Dulce (Roxb.) Benth. As highlighted by Guimarães et al. (2013), it is important to evaluate the dry matter of the plants because it is closely related to yield, and the response of plants in terms of dry matter accumulation depends on the environmental conditions, management, and species or genetic material used. These authors also claim that more vigorous seedlings have increased dry matter in their constitution and, consequently, are prepared for field conditions.

In relation to seedling height, there was significant difference for both treatments and accessions, and the accession $\mathrm{Apodi}_{3}$ was superior to the others (Table 2). The results referring to the treatments of scarification with sandpaper and cut with pruning pliers - T2 and T3, respectively, were superior to the others, obtaining higher means of seedling height (Table 3). Teles et al. (2000), testing dormancy breaking in seeds of white leadtree (Leucaena leucocephala (Lam.) de Wit) obtained increase, although small, in the values of height using scarification with sandpaper $n^{\circ} 120$, which positively influences 
the production of seedlings. Pereira et al. (2015), studying the behavior of seeds of Pithecellobium Dulce (Roxb.) Benth., obtained better values of shoot length in the treatment with sandpaper $n^{\circ}$ 80. Moreira et al. (2007b), evaluating emergence and initial growth of luffa seedlings, observed that this characteristic was influenced by the presoaking of seeds, which led to greater growth of seedlings in this treatment.

Table 2. Mean values of plant height (PH), root length (RL), number of true leaves (NTL), shoot fresh matter (SFM) and root dry matter (RDM) of luffa (Luffa cylindrica Roemer) seedlings as a function of different genotypes

\begin{tabular}{|c|c|c|c|c|c|}
\hline Accessions & $\mathrm{PH}(\mathrm{cm})$ & $\mathrm{RL}(\mathrm{cm})$ & NTL & SFM (g) & RDM (g) \\
\hline Apodi $_{1}$ & $6,00 c^{*}$ & $9,67 a^{*}$ & $1,32 b^{*}$ & $0,84 b^{*}$ & $0,02 c^{*}$ \\
\hline Apodi $_{2}$ & $6,49 \mathrm{bc}$ & $10,00 \mathrm{a}$ & $1,53 \mathrm{ab}$ & $0,94 \mathrm{~b}$ & $0,03 a b c$ \\
\hline $\mathrm{Apodi}_{3}$ & $7,90 \mathrm{a}$ & $10,01 a$ & $1,61 \mathrm{ab}$ & $1,33 \mathrm{a}$ & $0,04 a b$ \\
\hline Petrolina & $7,75 a b$ & $9,67 \mathrm{a}$ & $1,75 a$ & $1,11 \mathrm{ab}$ & $0,05 a$ \\
\hline Apodi $_{4}$ & $6,31 \mathrm{C}$ & $8,61 \mathrm{a}$ & $1,41 a b$ & $1,00 \mathrm{~b}$ & $0,03 \mathrm{bc}$ \\
\hline Serra Talhada & $6,60 \mathrm{bc}$ & $9,60 a$ & $1,31 \mathrm{~b}$ & $0,96 \mathrm{~b}$ & $0,02 \mathrm{bc}$ \\
\hline
\end{tabular}

In the evaluation of root length, there was no significant difference for any of the factors analyzed. The accession Apodi $_{3}$ obtained the highest mean compared to the others (Table 2) and the treatment of scarification with sandpaper $n^{\circ} 80$ - T2 obtained better result for root length (Table 3). Moreira et al. (2007b) analyzed emergence and initial growth of luffa seedlings and observed that pre-soaking influenced this characteristic. Araújo et al. (2015), testing dormancy breaking methods for Luffa operculata (L.) Cogniaux, found highest root length with tip removal followed by soaking in water for $24 \mathrm{~h}$.

For the number of leaves, significant differences were observed between accessions and between treatments (Table 2), and the accession Petrolina, had the highest mean. In relation to the treatments, the highest means occurred for the treatments with sandpaper $n^{\circ} 80$ and pruning pliers - T2 and T3, respectively (Table 3).

Table 3. Mean values of plant height (PH), root length (RL), number of true leaves (NTL), shoot fresh matter (SFM) and root dry matter (RDM) of luffa (Luffa cylindrica Roemer) seedlings as a function of different dormancy breaking methods

\begin{tabular}{clclll}
\hline Treatments & PH $(\mathrm{cm})$ & RL $(\mathrm{cm})$ & NTL & SFM $(\mathrm{g})$ & RDM $(\mathrm{g})$ \\
\hline T1 & $5,60 \mathrm{~b}^{*}$ & $9,01 \mathrm{a}^{*}$ & $1,16 \mathrm{~b}^{*}$ & $0,80 \mathrm{c}^{*}$ & $0,03 \mathrm{a}^{*}$ \\
$\mathrm{~T} 2$ & $8,20 \mathrm{a}$ & $10,30 \mathrm{a}$ & $1,73 \mathrm{a}$ & $1,23 \mathrm{ab}$ & $0,04 \mathrm{a}$ \\
T3 & $8,00 \mathrm{a}$ & $9,55 \mathrm{a}$ & $1,80 \mathrm{a}$ & $1,27 \mathrm{a}$ & $0,03 \mathrm{a}$ \\
$\mathrm{T} 4$ & $5,91 \mathrm{~b}$ & $9,72 \mathrm{a}$ & $1,35 \mathrm{~b}$ & $0,85 \mathrm{c}$ & $0,03 \mathrm{a}$ \\
T5 & $6,53 \mathrm{~b}$ & $9,40 \mathrm{a}$ & $1,40 \mathrm{~b}$ & $1,00 \mathrm{bc}$ & $0,03 \mathrm{a}$ \\
\hline
\end{tabular}

Evaluating emergence and initial growth of luffa, Moreira et al.(2007b) obtained positive results for this characteristic when the seeds were pre-soaked. Pereira et al. (2015) found much higher values for the same variable using sandpaper $n^{\circ} 80$, compared to the other treatments, in seeds of Pithecellobium Dulce (Roxb.) Benth.

With regard to the shoot fresh matter of the seedlings, differences were observed for both accessions and treatments, and the accession Apodi $_{3}$ obtained the highest mean (Table 2). Based on the treatments, it was observed that the cut on the opposite end to the hilum - T3 led to better result compared to the other treatments (Table 3). Moreira et al. (2007a), evaluating pregermination treatments for luffa seeds, observed that the best results of shoot dry matter occurred in seedlings grown from seeds subjected to treatments with sandpaper and cut with pruning pliers on the opposite end to the hilum.

The results of root dry matter differed significantly only between accessions, and Petrolina, obtained the highest mean (Table 2). For the treatments, they did not differ significantly from one another, but the one with sandpaper 
$n^{\circ} 80$ - T2 led to the highest mean for this variable (Table 3). Moreira et al. (2007b), evaluating emergence and initial growth of luffa seedlings, obtained positive relation of root dry matter with the treatment in which seeds were pre-soaked.

Among the treatments used in the present study, the ones which led to the best results were scarification with sandpaper $n^{\circ} 80$ and cut with pruning pliers on the opposite end to the hilum. These results can be attributed to the fact that luffa seeds have a naturally hard coat, which compromises the imbibition of water by the embryo. Therefore, using sandpaper or cut on the opposite end to the hilum facilitated the entry of water in the seed, favoring emergence. On the other hand, it is worth highlighting that the studies cited here used only one genotype (accession) of luffa, whereas the present study used different accessions, thus leading to greater heterogeneity in the results, and denoting the importance of not extrapolating the results when different genotypes are considered, since the variability inherent to them may result in different reactions when subjected to the same treatment. Willan (1990), evaluating dormancy breaking in seeds of Enterolobium contortisiliquum (Vell.) Morong., also found variation in the results when different lots were used. This author affirms that, due to this variability in the results, it was not possible to recommend one general method of dormancy breaking for the different accessions. Thus, this author proposed using in future studies higher number of progenies, in order to obtain consistent results which can be included in the Rules for Seed Analysis (Regras para Análise de Sementes - RAS)

\section{Conclusions}

The methods of scarification with sandpaper $n^{\circ} 80$ and cut with pruning pliers on the opposite end to the hilum led to the best results in dormancy breaking for the accessions of luffa seeds.

The variability of the results within the accessions does not allow for the recommendation of one method of dormancy breaking that is adequate for all accessions.

\section{References}

Alves, E.U., Cardoso, E.A., Bruno, R.L.A., Alves, A.U., Alves, A.U., Galindo, E.A, Braga Júnior, J. M. 2007. Superação da dormência em sementes de Caesalpinia pyramidalis Tul. Revista Árvore 31: 405-415.

Aragão, C.A., Deon, M.D., Queiroz, M.A., Dantas, B.F. 2006. Germinação e vigor de sementes de melancia com diferentes ploidias submetidas a tratamentos pré-germinativos. Revista Brasileira de Sementes 28: 82-86.

Araújo, P.C., Alves, E.V., Araújo, L.R., Alves, M.M., Medeiros, J.G. F. 2015. Tratamentos para superar a dormência de sementes de Luffa operculata (L.) Cogniaux. Revista Caatinga 28: 76-83.

Braga, R. 1979. Plantas do nordeste: especialmente do Ceará. UFC, Fortaleza, Brasil. $795 \mathrm{p}$.

Carvalho, N.M., Nakagawa, J. 2012. Sementes: ciência, tecnologia e produção. Funep, Jaboticabal, Brasil. 590 p.

Dutra, A.S., Medeiros Filho, S. 2009. Dormência e germinação de sementes de albízia (Albizia lebbeck (L.) Benth.). Revista Ciência Agronômica 40: 427-432.

Gnoatto, F.L.C., Cruz-Silva, C.T.A. 2011. Superação da dormência em sementes de pau-ferro (Caesalpinia ferrea Mart. ex Tul. var. leiostachya Benth.). Cultivando o Saber 4: 81-94.

Guimarães, I.P., Pereira, F.E.C.B., Silva, F.G., Araújo, M.D., Souza, P.S.L. 2013. Emergência e desenvolvimento de bucha (Luffa cylindrica Roemer) submetida a diferentes níveis de salinidade. Enciclopédia Biosfera 9: p. 989-997.

Leite, G.L.D., Moreira, E.D.S., Mota, V.A., Ferreira, I.C.P.V., Costa, C.A. 2011 . Artrópodes fitófagos e predadores associados em 20 acessos Luffa sp. em sistema orgânico. Revista Ciência Agronômica 42: 986-992.

Maguire, J.D. 1962. Speed of germination-aid in selection and evaluation for seedling emergence and vigour. Crop Science 2: 211-215.

Moreira, F.J.C., Innecco, R., Silva, M.A.P., Medeiros Filho, S. 2007(a). Tratamentos pré-germinativos em sementes de Luffa cylindrica Roemer. Revista Ciência Agronômica 38: 233-238.

Moreira, F.J.C., Silva, M.A.P., Medeiros Filho, S., Innecco, R. 2007(b). Emergência e crescimento inicial de plântulas de bucha (Luffa cylindrica Roemer.). Revista Ciência Agronômica 38: 169175.

Parreira, M.C., Cardozo, N.P., Pereira, F.C.M., Alves, P.L.C.A. 2012. Superação de dormência 
das sementes e controle químico de Momordica charantia (L.). Bioscience Journal 28: 358-365.

Pereira, F.E.C.B., Guimarães, I.P., Torres, S.B., Benedito, C.P. 2015. Superação de dormência em sementes de Pithecellobium dulce (Roxb.) Benth. Semina: Ciências Agrárias 36: 165-170.

Silva, A.G., Costa, L.G., Gomes, D.R., Brocco, V.F. 2012. Testes para quebra de dormência de sementes de Cassia grandis L. f. E, morfologia de sementes, frutos e plântulas. Enciclopédia Biosfera 8: 907-916.

Teles, M.M., Alves, A.A., Oliveira, J.C.G., Bezerra, M.E. 2000. Métodos para quebra de dormência em sementes de leucena (Leucaena leucocephala (Lam.) de Wit). Revista Brasileira de Zootecnia 29: 387-391.

Vivian R., Silva, A.A., Junior Gimenes, M., Fagan, E.B., Ruiz, S.T.; Labonia, V. 2008. Dormência em sementes de plantas daninhas como mecanismo de sobrevivência - Breve Revisão. Revista Planta Daninha 26: 695-706.

Willan, R.L. 1990. Seed pretreatment. Danida Forest Seed Centre, Humleaback, USA. 19p. 